\title{
The Construction of the Reality of Coverage Media Television about the Islamic Defenders Front
}

\author{
Puji Santoso $^{1,3}$, Syukur Kholil ${ }^{2}$, Syafruddin Pohan ${ }^{2}$ \\ ${ }^{I}$ Ph.D Student in State Islamic University of North Sumatera (UINSU), Medan, Indonesia \\ ${ }^{2}$ State Islamic University of North Sumatera (UINSU), Medan, Indonesia \\ ${ }^{3}$ Lecture in University of Muhammadiyah Sumatera Utara (UMSU), Medan, Indonesia \\ pujisantoso@umsu.ac.id
}

\begin{abstract}
The aim of this research is to analyze how the three national news television stations, MetroTV, KompasTV, and TVOne, tend to construct the news reality about Islamic organizations of Islamic Defenders Front in the period 2016-2017. The research method focuses on gathering, analyzing media content (framing studies), and mixing quantitative and qualitative data in one study or series of studies. The main premise is the use of mixed quantitative and qualitative approach, by providing an understanding of better research problems because it uses two approaches at once. The main instrument in this research was the researchers themselves who collected data through websites from three selected television media, in-depth interviews, participatory observation, and carried out relevant documentation studies related to objects of the research such as literature, BlogSpot, internet (online), e-journals, and reports of similar research results that are considered relevant. The results of this research show that the three news television stations studied, there were MetroTV, KompasTV, and TVOne has carried out construction on all the news that entered the newsroom, including news about the Islamic Defenders Front (FPI). Constructivist approaches assess that partiality and certain values cannot be eliminated from media coverage. Ethics, moral choice, and journalist and media alignments are the integral parts of news production. Ethics and morals in many ways mean partiality to one group or partiality to certain values. And it is generally based on certain beliefs as well. In addition, there were framing models that tended to be carried out by MetroTV, KompasTV, and TVOne. The framing model that tends to be carried out by the three news television media also tends to be different. From the models, the message and meaning are different from the audience or television viewers.
\end{abstract}

Keywords : media construction; media television; Islamic Defenders Front (FPI)

\section{Introduction}

Since the emergence of the blasphemy case involving the name of the former Governor of DKI Jakarta, Basuki Tjahaja Purnama or Ahok, the restlessness of the nation and Muslims are faced with sporadically and they try to efforts themselves and groups without command. Ghiroh of this resistance encouraged them to become cyber Muslim soldiers (MCA) who emerged without command and without pay. It turned out that the struggle was very effective in fighting the dominance and hegemony of mainstream media on social media. Now anything that is thrown at Muslims on social media will become a wild fireball and counterattack. ${ }^{1}$ On the other hand, after the actions of defending Islamic volumes 1,2 and 3 which were administered by the National Movement of Fatwa Guards (GNPF) of the MUI and the Islamic Defenders Front (FPI) in Jakarta recently, troops and Muslim unity were increasingly framed. The Muslim movement managed to penetrate the fortress of ignorance

\footnotetext{
${ }^{1}$ GdeSiriana, Muslims Uphold Mainstream Media Propaganda. See:

http://www.medanbagus.com/read/2016/12/09/44167/Umat-Islam-Melawan-Propaganda-Media-

Mainstream.html. (Accessed on Saturday, 10 December 2016 on 15.41 wib).
} 
and injustice that had been difficult to penetrate. This condition also undermines the stigma against Islam and also confirms that Islam in Indonesia is no longer based on group values, but as Islamic values. This can be proven by the abundance of Muslims from various archipelagos across mass organizations and schools about negotiating the road with the same agenda and ideals. This movement continues to be maintained and is made to remain intact and has great energy to constantly guard and rectify the regime that has come out of the khittah of the founding fathers of the nation. ${ }^{2}$ It needs to be deeply reflected in the history of the birth of this nation that the main actors in charge of the birth of this nation are those of the ulema. The ulema hand in hand contribute their energy, mind and blood to the birth of this nation.

Islamic mass organizations, Islamic Defenders Front or abbreviated as FPI, became a mass organization in charge of the spirit of diversity of Muslims from cases of blasphemy involving the name Basuki Tjahaja Purnama. However, the role of FPI has not always received the attention of mainstream media, both print and TV media and online media. The mass media has given a negative stigma to the FPI as an anti-religious organization. Often called FPI there is no place in the news in the mass media of television and special print media. FPI's attitude towards opposing and the existence of Ahok as the Governor of DKI was approved as a form of disagreement.

\section{Review of Literatures}

\subsection{Constructivism Theories}

Discussing the theory of social construction, certainly cannot be separated from the theoretical building that has been proposed by Peter L. Berger and Thomas Luckmann. Peter L. Berger is a sociologist from New School for Social Research, New York. While Thomas Luckmann is a sociologist from the University of Frankfurt (Germany). Social construction theory is actually formulated by these two academics as a theoretical and systematic study of the sociology of knowledge. ${ }^{3}$ This theory is rooted in the constructivism paradigm that sees social reality as a social construct created by individuals who are free humans. Individuals become erratic in the social world constructed according to their will. Also with this theoretical framework, according to Hamad, we can even weigh the attitudes (motivations) of each media in reporting political events. Basically, every media has the freedom to choose the political language and the facts that will be used in the text it makes depends on the consideration of external and internal factors. Similarly, every media is free to load or not broadcast a text that has been made. It is precisely with the freedom to make text (discourse) that we can uncover the motivation and purpose of each media behind the text (or image) it makes, whether it is ideological, idealistic, economic, or political motives.

\footnotetext{
2 The act of defending Islam in volume 3 at the National Monument (Monas), Jakarta, on December 2, 2016 which came to be known as the "212" action announced about the mass of Muslims who needed around 7 million people. The action became a mass action with the most mass numbers ever in Indonesian history. The researcher who took part directly in the action "212" really enjoyed the atmosphere of extraordinary Islamic spirit in understanding Islam and also receiving the Qur'an which was defamed by Basuki Tjahaja Purnama or Ahok.

${ }^{3}$ Dadang Sugiana. Konstruksi Identitas dan Perilaku Komunikasi Komunitas Penggemar MusikKoes Plus dan Koes Bersaudara. (dissertation). Universitas Padjajaran. Bandung. 2013. p.54.
} 


\subsection{Framing Theory}

The idea of framing theory was first put forward by Beterson in $1955 .{ }^{4}$ Initially, the frame was interpreted as a conceptual structure or set of beliefs that organized political views, policies, and discourses, and which provided standard categories to appreciate reality. This concept was further developed by Goffman in $1974^{5}$, which presupposes frames as strips of behavior that guide individuals in reading reality. Lately, the concept of framing has been used extensively in the communication science literature to describe the process of selecting and highlighting specific aspects of reality by the media. In the realm of communication studies, framing analysis represents a tradition that prioritizes multi-disciplinary approaches or perspectives to analyze phenomena or communication activities. The concept of framing or frame itself is not purely a concept of communication science, but borrowed from cognitive science (psychological). In practice, framing analysis also opens opportunities for the implementation of sociological, political and cultural concepts to analyze communication phenomena, so that a phenomenon can be appreciated and analyzed based on the sociological, political, or cultural context that surrounds it. ${ }^{6}$

In a communication perspective, framing analysis is used to dissect media methods or ideologies when constructing facts. This analysis looks at the selection strategies, prominence, and linking facts to the news so that they are more meaningful, more interesting, more meaningful or more memorable, to lead the interpretation of the audience according to their perspective. ${ }^{7}$

\subsection{Media Coverage}

News in one station broadcasting institution is a program that becomes the main attraction of one broadcasting institution concerned to the viewers or its audience. This can be the reason for every new audience to choose or move to the television station. The news program is a presentation that conveys all the actual events concerning social, political, environmental, public policy, etc. issues, both those that occur when the news is displayed (current event / affair) and the news that is happening (on going event). If the event has been going on for a while, then the category is no longer news, but has been included as a news magazine or features. ${ }^{8}$ Whereas News is a terminology in journalistic science whose definition or limit is as follows: "News is the timely report of fact or opinion, to hold interest, importance, or both, for a considerable number of people". Meaning: "News is a description of events / facts and or opinions, which contain news values, and which have been presented through mass media periodically". ${ }^{9}$ According to Hamad, the news is a discourse. The news that exists now is a construction of reality, not the actual reality. The discourse presented in it has several levels, among others, framing, signing, and friming. ${ }^{10}$ Of the several notions of

\footnotetext{
${ }^{4}$ Sudibyo (1999) in Sobur. p.161.

${ }^{5}$ Ibid. p. 162.

${ }^{6}$ Sudibyo (1999) in Sobur. p. 162.

${ }^{7}$ Imawan (2000) in Sobur. p. 162.

${ }^{8}$ Hidajanto Djamal. TV Programing: Sebagai Satu Kesisteman Untuk Meraih Jumlah Audiens Secara Optimal. First Edition. Publisher: Kencana. Jakarta 2017. p.89

${ }^{9}$ Charnley in Wahyudi (1996) in Noneng Sumiaty and Neti Sumiati. Jurnal Penelitian Komunikasi Volume 18 No.1, July 2015. p.69-78.

${ }^{10}$ Hamad. in Jurnal Penelitian Komunikasi Vol. 18 No.1, July 2015. p.69-78.
} 
the news above, only the understanding compiled by Charnley was the most complete. From this understanding it can be seen that the news is not an event / fact and or opinion, but a description that has been presented through periodic mass media. All news is information, but not all information is news, because news is information that contains news values that have been processed in accordance with the rules that exist in journalistic science, and which have been presented to the public through periodic mass media, both print and electronic. ${ }^{11}$

Reality in the community, such as events, opinions, warm issues, and unique problems will produce facts, and only a description of facts containing news values and those that have been presented through periodic mass media which can be called news. ${ }^{12}$ In wikipedia, the definition of news is written, namely new information or information about something that is happening that is presented through print (media), broadcast, internet, or word of mouth to a third person or many people. ${ }^{13}$ News reports are the job of the journalist profession, when the news reported by reporters the report then becomes the latest facts / ideas that are deliberately chosen by the editorial staff (editors) of the news / media to be broadcast on the assumption that the selected news can attract large audiences because they contain elements news. TV stations usually have news programs or broadcast news all the time. The need for news is in the community, both literate and illiterate. ${ }^{14}$

\subsection{Television News}

Television is the dominant news information media. Large resources are devoted to that. News is in line with the cutting edge of new technology because it is used to accessing sounds and images immediately from around the world. Of course this is a cultural phenomenon. Because of this, the news is also the object of critical attention, because it is present before us with a special view of the world that it sells to us as the only view that is worthy of being adopted. This made the news an ideological operation, which was present because he carried out the election of views on politics, economics, society - in short, a view of power. For example, the news is a matter of power when it is 'experienced', when it is 'diseogiakan'. This chapter looks at a series of critical ideas about television news which are essentially constructed. ${ }^{15}$

\subsection{Islamic Defenders Front}

In one article the researcher quoted in a blogspot, the FPI organization was declared on August 17, 1998 (or 24 Tsani Rabiuts 1419 Hijri) on the page of Al Umm Islamic Boarding School, Kampung Utan, Ciputat, South Jakarta by a number of Habaib, ulama, mubaligh and Muslim activists and witnessed by hundreds of santri from Jabotabek regions. The establishment of this organization was only four months after President Soeharto resigned his position, because at the time of the new order the president did not tolerate extremist acts in any form. ${ }^{16}$ But based on a book written by Al Habib Muhammad Rizieq Bin Husein Syihab, the Islamic Defenders Front (FPI) was established on the 25th Robi'uts Tsani 1419 Hijriyyah

\footnotetext{
${ }^{11}$ Ibid.

12 Wahyudi in Noneng and Neti. Ibid.

${ }^{13}$ See Wikipedia in http://id.m.wikipedia.org (Accessed on tuesday, 16 May 2017, at 9.48 Wib)

${ }^{14}$ Ibid.

${ }^{15}$ Graeme Burton. Talking Television: An Introduction to The Study Talk Television(Membincangkan Televisi: Sebuah Pengantar Kepada Kajian Televisi). Translation. Publisher: Jalasutra. Yogyakarta. 2007. P.197-.223.

16 See: https://makalahkomplit.blogspot.co.id/2012/12/sejarah-berdirinya-fpi.html (Accessed on thursday 15 March 2018, at 20.31 Wib)
} 
to coincide with the 17th August 1998 Miladiyah (AD). According to Rizieq, FPI was founded by a number of Habaib and ulama and thousands of Muslims in Jakarta.

\subsection{Framing Media in Islamic Perspectives}

The term "communication" itself is very much found in various literatures, especially those that discuss communication science and theories. Some definitions of "communication" that the writer can convey in this paper include quoting Deddy Mulyana, as follows that the term communication or communicaton comes from Latin communis which means 'same'. Communico, communication, or communicare which means making the same (make to common). In simple terms, communication can occur if there is a similarity between the delivery of the message and the person receiving the message. ${ }^{17}$ Therefore, according to West, Richard \& Lynn H. Turner, communication depends on our ability to understand one another (communication depends on our other ability to understand one). ${ }^{18}$

Al-Qur'an calls communication one of human nature. To find out how humans should communicate, the Qur'an gives a key word (keyconcept) related to it. Key words used by the Qur'an for communication-qaul.Darial-qaulini, Jalaluddin Rakhmat describe the principle, qaulan sadly is the ability of blessings or communicates well. ${ }^{19}$ According to researchers, communication is the oldest activity in nature. Both real and supernatural nature. Long before communication stood in a scientific discipline. Especially so far before the theories of communication were discovered. Communication activities have already existed as the Qur'an before, hinting at this in many verses. The communication activities are included in Al Quran surah Al Baqarah verses 30 to 37, namely when Allah Subhaanahu wa Ta'aala mentions the first human story of the Prophet Adam 'alaihis salam, His creation and how. He privileged Adam with khilafah and science.

In the Islamic perspective, communication is an integral part of human life because all of our moves are always accompanied by communication. Communication in question is Islamic communication, namely communication with the character of al-karimah or ethical. Communication that has the character of al-karimah means communication originating from the Koran and hadith (the Sunnah of the Prophet). These ethical principles can actually be used as a foundation for every Muslim in the process of communication, both in daily life, preaching, and other activities. In the Qur'an we easily find concrete examples of how God always communicates with His servants through revelation. To avoid mistakes in receiving messages through these verses, Allah also gives freedom to RasuluLlah to reduce His revelation through the matan hadith. Both the hadith are Qouliyah (sayings), Fi'iliyah (deeds), Taqrir (approval) of the apostles. Then coupled with the birth of interpreters so that through their hands collected so many interpretive books. ${ }^{20}$ In addition, we find RasuluLlah SAW in communicating with family, friends and followers. His communication has accumulated in hundreds of thousands of hadiths that have reinforced the Qur'an's explanation as a guide to human life.

\footnotetext{
${ }^{17}$ Deddy Mulyana. Imu Komunikasi Suatu Pengantar. PT Remaja Rosdakarya. Bandung. 2007. P.17.

18 West, Richard \& Lynn H. Turner. Introducing Communication Theory. Third Edition. Singapore: The McGrow Hill Companies. 2007, p. 67.

${ }^{19}$ Rahmat, Jalaluddin.Efektivitas Berkomunikasi dalam Islam. CetI;Bandung: Mizan, 1999, p. 35.

${ }^{20}$ http://amarsuteja.blogspot.co.id/2012/10/.html
} 


\section{Research Methods}

This research method focuses on collecting, analyzing, and mixing quantitative and qualitative data in one study or series of studies. The main premise is the use of quantitative and qualitative approaches in combination, providing better understanding of research problems because it uses two approaches at once. According to Sugiyono, to be able to conduct research using a combination method (MetKom), the characteristics of the two methods must be understood in advance. One difference between quantitative research methods and qualitative methods lies in the foundation of philosophy, or basic axioms.

The philosophical foundation is related to the view of reality, symptoms or data. Quantitative methods are based on positivism philosophy. This philosophy holds that a symptom can be grouped, observable, measurable, and causal, relatively fixed and value free. Because symptoms can be grouped, quantitative researchers can choose several variables in their research. The level of quantitative research difficulties can be measured by the number of variables studied. For example research for S1 can be with two independent variables one dependent. S2 research is more than that, the relationship model of variables can be in the form of pathways which are analyzed by path analysis. The study of S3 research variable students is more than S2, for example with the relationship model. Variables in the form of Structural Equation Model (SEM), which is a development of path analysis. ${ }^{21}$

Because symptoms can be observed, and measured, the researcher in making observations uses a measuring instrument that has been tested for validity and reliability. Because the symptoms are causal, the researcher in conducting his research, besides describing the value of the observed variables, also conducts research that is cause and effect, looking for the effect of independent variables on the dependent variable so that the research title uses the words "influence, contribution, determinant factors".

Quantitative research views that a symptom is considered to be relatively fixed, does not change in a certain time. Thus the results of quantitative research can be declared valid and reliable in a relatively long time. Because research results are valid for a relatively long time, quantitative researchers can make predictions more accurately. Quantitative researchers in viewing symptoms are value-free. Value-free is the data obtained is not influenced by subjective factors of researchers and data sources. This happens because between researchers and data sources often do not interact. By using data collection techniques with questionnaires and samples taken randomly, so that researchers have no direct contact with the data source. Thus the data obtained is objective and value-free data.

\section{Discussion}

After the researchers conducted research on the number of news about FPI, especially related to the uproar coverage of the DKI Jakarta Pilkada and Action Super Peace 212 on tvOne, KompasTV, and MetroTV during the 2016 and 2017 periods, quantitatively, the news about the activities of the PFI organizations on the three TV stations turned out not the same as the number of news items and the frequency of the news. In this case, the researchers coding the news by choosing the news about FPI which the researchers value most prominently, the framing elements that are broadcast on each news TV station studied.

${ }^{21}$ Sugiyono. Metode Penelitian Kombinasi. Print 8. Publisher: Alfabeta. Bandung. 2016. P.309-413 
Quantitatively, the number of news items broadcast by MetroTV, KompasTV, and TVOne is seen in the table as follows:

Table 1. Quantitative Assessment on TVOne, MetroTV, and KompasTV FPI News Live Period 2016 - 2017

\begin{tabular}{|c|c|c|c|c|}
\hline \multicolumn{5}{|c|}{ tvOne } \\
\hline \multirow{2}{*}{ Item } & \multicolumn{2}{|c|}{2016} & \multicolumn{2}{|c|}{2017} \\
\hline & Soft news & Hard news & Soft news & Hard news \\
\hline Law Enforcement & 3 & 7 & 1 & 9 \\
\hline Speech & 3 & - & - & - \\
\hline Violence & - & 1 & - & - \\
\hline Social action & - & - & - & - \\
\hline \multicolumn{5}{|c|}{ MetroTV } \\
\hline \multirow{2}{*}{ Item } & \multicolumn{2}{|c|}{2016} & \multicolumn{2}{|c|}{2017} \\
\hline & Soft news & Hard news & Soft news & Hard news \\
\hline Law Enforcement & 3 & 8 & - & 19 \\
\hline Speech & - & - & - & - \\
\hline Violence & - & 1 & - & - \\
\hline Social action & - & - & - & 1 \\
\hline \multicolumn{5}{|c|}{ KompasTV } \\
\hline \multirow{2}{*}{ Item } & \multicolumn{2}{|c|}{2016} & \multicolumn{2}{|c|}{2017} \\
\hline & Soft news & Hard news & Soft news & Hard news \\
\hline Law Enforcement & 1 & 9 & 1 & 13 \\
\hline Speech & - & 1 & - & 3 \\
\hline Violence & - & 1 & - & - \\
\hline Social action & - & 2 & - & - \\
\hline
\end{tabular}

After analyzing textually and visually, the researchers gave an interpretation of the news about FPI aired by MetroTV during the period of 2016-2017. In the MetroTV editorial policy, the editor in chief at the newsroom was strongly tied to the ideology adopted by the MetroTV founder and owner Surya Paloh. All policy coverage on MetroTV may not shift in the least from the principles of ideology of the owner. Surya Paloh is a very important figure and influences every business and business under the Media Group business banner. Surya Paloh is active in the field of media business, namely Media Indonesia, Lampung Post, and MetroTV. In the political field, Surya is also very active. Surya Paloh was listed as the person who first gave birth to the birth of the National Democratic Political Party (NasDem Party). Until now Surya is still listed as General Chair of the NasDem Party. Of course there is not a small amount of money that he incurred to build television broadcasters and media institutions and political institutions. In fact, Surya Paloh has decided that the party he leads is a party affiliated and supports the ruling government led by President Joko Widodo. In each of his political speeches in various regions in North Sumatra that followed researchers, 
Surya Paloh emphatically said that he and his party not only supported, but also helped maintain the continuity of power under the leadership of Joko Widodo. If the ideology of the NasDem Party is nationalism, then the ideology of MetroTV also follows the ideology of the NasDem Party built by Surya Paloh to support power.

Furthermore, based on the analysis and discussion earlier, the researchers can interpret based on what Teun A Van Dijk said about the existence of a lot of information in a text not explicitly stated, but implicit. Words, clauses, and other textual expressions and the visuals displayed by the media may suggest concepts or propositions (statements about things that can be considered right or wrong) that can be predicted based on the knowledge that is the background. This feature of discourse and communication has important ideological dimensions. Analysis of what is not said is sometimes clearer than the study of what is actually said in the text. In short, news is a way to create the desired reality about the events or (groups) of people reported.

KompasTV's editorial policy can almost certainly not be far from the main ideas and values adopted by Kompas Daily and its founder Jakob Oetama. Transcendental humanism, press freedom, and the Kompas General Daily, are colorful mosaics that lie behind the figure of Jakob Oetama. Together with Petrus Kanisius Ojong (PK Ojong), Jakob Oetama founded, pioneered, developed the Kompas newspaper, which was first published on June 28, 1965. Transcendental humanism, according to Kees de Jong and Policarpus Swantoro, was Jakob Oetama's findings. Transcendental humanism is an identity, a process as well as an inspiration for the Kompas Daily. Kees de Jong said, transcendental humanism means humanity. Humanity means not humanity, not humanity, socialist, communist, secular, but humanity that is equipped with trust in God and trust in the values that perfect. In the formulation of humanity contained in the meaning of compassion, namely sympathy towards others, sharing feelings of emotion and its shortcomings is the image of God as well as a menu of humiliation that must be respected, his rights must be respected and placed as the main value.

Based on observations and interpretations of researchers, a number of KompasTV news that aired news about FPI during the period of 2016 and 2017, the editorial of KompasTV carried out construction on the FPI news that he wanted to air. Among others, conducting editorial meetings followed from the producer level, reporters, and editors. In fact, almost every day KompasTV always participates in synergy meetings with other media in one group with Kompas Gramedia Group, namely Kompas and Kompas Online Daily (kompas.com). Joint meetings held almost every day starting at 10.00 WIB always discuss and determine what topics and issues will be the main report for KompasTV to show, but also published in Kompas and Kompas Online. In particular for news related to FPI, KompasTV did not admit that they were framing the FPI news that KompasTV aired. If the framing action is considered to be detrimental to other parties, then KompasTV feels that there is no need to framing the FPI news they broadcast. The principle of balance is the absolute basis of KompasTV in carrying out their fractional operations.

Among the three news television studied, there are MetroTV and KompasTV, TVOne television has a different tendency to report FPI compared to MetroTV and KompasTV. TVOne television station based on the research that the researchers did, tended to be accommodative of the news about FPI. The two most prominent things about TVOne's report on FPI were the full reporting of Friday's sermon Habib Rizieq Syihab on Friday in the arena of the Super Peaceful Action 212 at the National Monument on December 2, 2016. Secondly, 
tvOne is very consistent in mentioning the title "Habib" to Rizieq Syihab, so almost never found news about FPI on tvOne does not use the title "Habib" every time it mentions the name Habib Rizieq Syihab. In fact, the TVOne claimed to have never placed Islamic organizations like FPI as the most special Islamic organizations compared to other Islamic organizations or other community groups. "We have never prioritized FPI in any news policy on TVOne. Our priority is news value. That is our judgment. As far as how the magnitude of the event is to the public, we are worthy to report it, "said Deputy Editor in Chief of TVOne, Totok Suryanto, to researchers at the tvOne editorial office in Jakarta. When almost all televisions did not preach Friday Habib Rizieq Syihab's sermon on December 2, 2016 at Monas, tvOne became the only one to fully report the Friday sermon. Even though Habib Rizieq's Friday sermon visual image which was aired on TVOne did not come from tvOne's own production, it relayed from TVRI. This is known from the visual of the show, where the writing and TVRI logo on the top right are listed on the tvOne frame. When examined the contents of the Friday sermon delivered by Habib Rizieq Shihab, it contains the firmness of God in the Qur'an not to rule to the laws of other regulations other than the law of Allah and His Messenger, namely Al Quran and Hadith. The researcher who was also present at the Super Peaceful Action 212 at Monas, also listened to the Friday khutbah Habib Rizieq who conveyed firmly and loudly, that if the constitutional verses (state) were contrary to God's law, then they must be firmly rejected. But if the constitutional verses are in accordance with the verses of the Qur'an, then it is obligatory for Muslims to obey them. Habib Rizieq's Friday Khutbah was also attended and heard by President Jokowi, National Police Chief Gen. Tito Karnavian, then TNI Commander namely TNI General Gatot Nurmantyo, Coordinating Minister for Politics and Security Wiranto, and a number of other state officials such as Luhut Binsar Panjaitan, and others. Of course for TVOne viewers throughout Indonesia, especially among Muslims, who did not have time to attend the 212 Peace Action at Monas, they could just watch Habib Rizieq's Friday sermon which was broadcast live.

\section{Conclusion}

Based on subjective analysis and interpretation of researchers, reporting on FPI that was broadcast by MetroTV, KompasTV, and TVOne during 2016-2017 was realized or not, intentionally or not, the three news television media studied were the tendency to framing news related to FPI and leaders and administrators and FPI members. Only, the news managers in the newsroom of each news television station claimed that the construction of the news reality in the newsroom was natural and did not feel framing on all the news about FPI that entered the newsroom or editorial room.

\section{References}

Al Quranul Karim. Cetakan Kementerian Agama RI. Jakarta. 2003.

Afifuddin and Ahmad Saebani, Beni. Metodologi Penelitian Kualitatif. Publisher: CV Pustaka Setia. Bandung. 2012.

Armando, Ade. Televisi Indonesia di Bawah Kapitalisme Global. PT Kompas Media Nusantara. Jakarta. 2016.

Ardianto, Elvinaro; Komala, Lukiati Komala; Karyanti S, Siti. Komunikasi Massa: Suatu Pengantar. Publisher: Simbiosa Rekatama Media. Bandung. 2014

Qomaruzzaman, Bambang. Filsafat Ilmu Komunikasi. Publisher: Simbiosa 
Rekatama Media. Bandung V edition. 2016.

Bajari, Atwar. Metode Penelitian Komunikasi: Prosedur, Tren, dan Etika. Publisher: Simbiosa Rekatama Media. Bandung. 2015.

Basorie, Warief Djajanto and Atmakusumah (peny). Meningkatkan Etika Jurnalistik. Lembaga Pers Dr. Soetomo (LPDS) and Nowegian Embassy. Jakarta. 2011.

Bungin, Burhan. Sosiologi Komunikasi, Teori, Paradigma dan Diskursus Teknologi Komunikasi di Masyarakat. Jakarta: Kencana Prenadamedia Group, Jid.14, 2014

Budianto, Heri and Farid Hamid (Ed). Ilmu Komunikasi Sekarang dan Tantangan Masa Depan. Prenadamedia Kencana. Jakarta. 2013.

Burton, Graeme. Talking Television: An Introduction to The Study Talk Television on (Membincangkan Televisi: Sebuah Pengantar Kepada Kajian Televisi). Translation. Publisher: Jalasutra. Yogyakarta. 2007.

Cresswell, John W. Research Design: Pendekatan Kualitatif, Kuantitatif, dan Mixed (translted). 3 edition. 4 print. Publisher: Pustaka Pelajar. Yogyakarya.2014.

Djamal, Hidajanto. TV Programing: Sebagai Satu Kesisteman Untuk Meraih Jumlah Audiens Secara Optimal. First Edition. Publisher: Kencana. Jakarta 2017.

Eriyanto. Analisis Framing, Konstruksi, Ideologi, dan Politik Media. Yogyakarta: LkiS 2002.

Erner J. Severin, James W. Tankard, JR. Teori Komunikasi Sejarah. Metode, dan Terapan didalam Media Massa. 5 print. Translated by Sugeng Hariyanto. Jakarta:Kencana. 2011.

Hamad, Ibnu. Konstruksi Realitas Politik dalam Media Massa: Sebuah Studi Critical Discourse Terhadap Berita-berita Politik. Publisher: Granit. Jakarta. 2004.

Hamka, Tafsir Al Azhar. Publisher: Gema Insani Press. Jakarta. 1988.

Hefni, Harjani. Komunikasi Islam. Jakarta: Kencana Prenadamedia Group. 1 printed. 2014.

Hill, David T. The Press in New Order Indonesia. Translation. Publisher: PT Pustaka Sinar Harapan.Jakarta. 1994.

Ibnu Katsir, Imam. Tafsir Ibnu Katsir. The Origin Title of the Kitab: Tafsir Al-Qur'an Al-'Adzim. Translators: Arif Rahman Hakim, MA; Syahirul Alim Al-Adib, Lc; Muhammad Zaini; Nila Nur Fajariyah; Muh. Faqih Fatwa, Lc. Publisher: Insan Kamil. Jakarta. 2016.

Imaduddin Abdurrahim, Muhammad. Kuliah Tauhid. Pustaka Salman. Bandung. 1990.

Ida, Rachmah. Metode Penelitian Studi Media dan Kajian Budaya. Prenada MediaGroup. Jakarta. First Printed. 2014.

Ishak, Aswad, at el (ed). Mix Methodology Dalam Penelitian Komunikasi. Publisher: Buku Mata Padi Presindo. Yogyakarta. 2011. .Jurnalisme TV Indonesia: Tinjauan Luar Dalam. IJTI. Jakarta. 2010.

Bandung.2011. . Metodologi Penelitian Komunikasi. Perdana Publishing. Medan. 2016

Kriyantono, Rahmat. Teknik Praktis Riset Komunikasi. Penerbit Kencana Prenadamedia Group. Jakarta. 7 printed. 2014.

Latief, Rusman and Yusuatie Utud. Siaran Televisi Non-Drama. Prenadamedia Group.Jakarta. 2015. . Menjadi Produser Televisi. Prenadamedia Group. Jakarta. 2017.

Liliweri, Alo. Metode Campuran Kuantitatif dan Kualitatif. Makalah yang disajikan dalam seminar Mixed Methods Research, in event of Dies Natalis ke 37 Fakultas IlmuSosial dan Ilmu Politik, Universitas Sumatera Utara, Medan, at 15 September 2017 in Medan.

Louw, P. Eric. The Media and Political Process. SAGE Publications Ltd. California. USA. 2005.

Luigi, Monte Selvanus, Widi Astuti, and Yannah Akhras. Hari Ini Kita Bela Al-Qur'an Semoga Kelak Al-Qur'an Membela Kita. Publisher: Istanbul. Jakarta. 2017.

Morrisan. Teori Komunikasi Massa Individu Hingga Massa. Jakarta: KencanaPrenadamedia Group. Cetakan ke 2. 2014.

. Jurnalistik TV Mutakhir. Publisher: Kencana Prenada Media. Jakarta. 2008

Mulyana, Deddy . Ilmu Komunikasi Suatu Pengantar. PT Remaja Rosdakarya. Bandung. 2007. 
Mufid, Muhammad. Komunikasi \& Regulasi Penyiaran. Prenadamedia Group dan UIN Pers. Jakarta. 2014

Muhammadi, Fikry. Sisi Lain Habib Rizieq. Publisher PT Zaytuna Ufuk Abadi. Jakarta. 2017.

Natsir, Muhammad. Fiqhud Dakwah. Publisher Dewan Dakwah Islamiah Indonesia. Jakarta 2000.

Nugroho, Y., Putri, DA., Laksmi, S. 2012. Memetakan Lanskap Industri Media Kontemporer $\quad$ di Indonesia (Edisi Bahasa Indonesia). Laporan. Bermedia, Memberdayakan Masyarakat: Memahami kebijakan dan tata kelola media diIndonesia melalui kacamata hak warga negara. Riset kerjasama antara Centre for Innovation Policy and Governance dan HIVOS Kantor Regional Asia Tenggara, didanai oleh Ford Foundation. Jakarta: CIPG dan HIVOS.

Rahmat, Jalaluddin.Efektivitas Berkomunikasi dalam Islam.Bandung: Mizan. I printed.1999.

Roem, Elva Ronaning. Konstruksi Realitas Sosial Tentang Pelacuran Melalui Pengalaman Komunikasi Pelaku Seks Komersial: Studi Fenomenologi di Kota Padang, Propinsi Sumatera Barat.(Dissertation). Universitas Padjadjaran. Bandung. 2017

Simanjuntak, Saor. KPI and Masa Depan Industri Televisi. Makalah di dalam buku Haris Jauhari (Ed) berjudul Jurnalis Televisi Indonesia: Tinjauan Luar Dalam. Penerbit PT Gramedia. Jakarta. 2012.

Sobur, Alex. Analisis Teks Media: Suatu Pengantar untuk Analisis Wacana, Analisis Semiotik, dan Analisis Framing. PT Remaja Rosda Karya. Bandung. Cetakan ke Enam. 2014.

Sudibyo, Agus. Kebebasan Semu: Penjajahan Baru di Jagad Media. PT Kompas Media Nusantara. Jakarta. 2009.

Sugiana, Dadang. Konstruksi Identitas dan Perilaku Komunikasi Komunitas Penggemar Musik Koes Plus dan Koes Bersaudara. (Dissertation). Universitas Padjajaran. Bandung. 2013.

Sugiyono. Metode Penelitian Kombinasi (Mixed Methods). 8 print. Publisher CV Alfabeta. Bandung. 2016.

Sularto.St. (ed). Humanisme Dan Kebebasan Pers. Publisher Buku Kompas. Jakarta. 2001

Syam, Nina W. Model-model Komunikasi: Perspektif Pohon Komunikasi. PT Simbiosa Rekatama Media. Bandung. 2013

Syaefudin, Machfud. Reinterpretasi Gerakan Dakwah Front Pembela Islam (FPI). Jurnal Ilmu Dakwah STAIS Pekalongan, Vol. 34, No.2, July - December 2014 ISSN 1693-8054.

Stephen W. Littlejohn, Karen A. Foss. Theories of Human Communication. Belmont California. 9 edition. Penerjemah Muhammad Yusuf Hamdan. Jakarta: Salemba Humanika.

Perdana, Andhika; Karlinah,Siti; Yudhapramesti,Pandan. Lihat:eJurnal Mahasiswa Universitas Padjadjaran Vol.1, No.1 (2012). see: http://journals.unpad.ac.id

Pohan, Syafruddin. Ekonomi Politik Media: Sejarah, Teori, dan Penerapan. Penerbit USU Press. Medan. 2016.

Poerwadarminta, W.J.S., Kamus Besar Bahasa Indonesia, Cet VII, Balai Pustaka, Jakarta, 1984, p. 1031. (see: http://digilib.unila.ac.id/2827/12/BAB\%20II.pdf)

Werner J. Severin, James W. Tankard, Jr. Teori Komunikasi Sejarah, Metode, dan Terapan di Dalam Media Massa. Jakarta: Kencana Prenadamedia Group. 5 edition. 2011.

West, Richard \& Lynn H. Turner. Introducing Communication Theory. Third Edition. Singapore: The McGrow Hill companies. 2007

Undang-undang No. 40 tahun 1999 tentang Pers.

Undang-undang. No. 32 tahun 2002 tentang Penyiaran.

Peraturan Komisi Penyiaran Indonesia (KPI) Tentang Pedoman Perilaku Penyiaran Standar Program Siaran (P3 SPS) 2012

\section{Journals}

BM, Mursito. Konstruksi Realitas dalam (Bahasa) Media. Jurnal Komunikasi Massa. Universitas Negeri Surakarta. Solo. Vol. 1, No. 1, July 2007, 25-34. 2007.

Dina Oktaviani. e-Journal Ilmu Komunikasi Universitas Mulawarman. Samarinda. Volume 32015. 
Kadewandana, Donie. E-Jurnal Komunikasi UIN Syarif Hidayatullah. Volume 5. Jakarta. 2009.

Kholisoh, Nur. Konstruksi Peran Politik Perempuan di Media. Jurnal Ilmu Komunikasi“Wacana" Universitas Prof. Dr. Moestopo (Beragama). Jakarta. Volume XIV. Nomor 4. November 2015.

Pawito. Jurnal Komunikasi Profetik, Jurusan Ilmu Komunikasi FISIP Universitas Sebelas Maret

Surakarta. Vol. 7, No. 1, April 2014. (seehttps://media.neliti.com/media/publications/224255meneliti-ideologi-media-catatansingkat.pdf)

Pola Yogi Hardani and FX Sri Sadewo, E-Jurnal Ilmu-ilmu Sosial, Fakultas Ilmu Sosial

Universitas Negeri Surabaya. Volume 3. Surabaya. 2014.

\section{Internet}

http://agustocom.blogspot.co.id/2010/06/konstruksi-sosial-atas-realitas-dan.html.

(posted on 18 September 2016 at $19.20 \mathrm{Wib}$ )

http://madkartam.blogspot.co.id/konstruksi-sosial-media-massa.html. (posted on 18

September 2016 at $19.04 \mathrm{Wib})$

http://sp2010.bps.go.id/index.php/site/tabel?tid=321 (Accessed on Sunday, 30 April 2017) at 20.50 Wib).

http://www.voa-islam.com/read/indonesiana/2013/08/21/26398/fpi-laporkan-sejumlah mediapenyebar-berita-bohong-ke-dewan-pers/\#sthash.qdbUsMAD.dpuf (Accessed on Sunday, 30 May 2017, at $16.32 \mathrm{Wib}$ )

lihat: $\quad$ http://www.voa-islam.id/read/indonesiana/2013/08/22/26407/jelang-munas-fpi-habib rizieq-bicara-soal-lamongan-kendal-tasik/.( Accessed on Monday, 1 May 2017 at 18.02).

http://www.infoteratas.com/2017/01/terjawab-sudah-ternyata-ini-perihal.html (Accessed on Sunday, $30 / 4 / 2017)$ at 14.56 .

http://www.nielsen.com/id/en/press-room/2016/pertumbuhan-belanja-iklan-menunjukkan arahpositif.html. (Accessed on Sunday, 30 April 2017, at 16.30).

http://www.nielsen.com/id/en/press-room/2014/nielsen-konsumsi-media-lebih-tinggi-di-luar jawa.html (Accessed on Sunday, 30 April 2017, at 16.34).

http://onierbana.blogspot.co.id/2015/10/media-profile-kompas-TV-media.html (Accessed on Monday, 1 Mei 2017, at 13.46).

http://id.m.wikipedia.org (Accessed on Tuesday, 16 May 2017, at 9.48 Wib)

http://menulisproposalpenelitian.com/2012/07/reduksi-data-dalam-analisis penelitian.html?m=1 (Accessed on Tuesday 16 May 2017 at $8.10 \mathrm{Wib}$ ).

http://anggiwidyalestari.blogspot.co.id/2016/09/unit-analisis.html (Accessed on Saturday 22 Juy 2017 at 11.45)

http://www.referensimakalah.com/2012/09/pengertian-unit-analisis-dalam-penelitian.html.

(Accessed on Saturday 22 July 2017 at 11.55)

http://follyakbar.blogspot.co.id/2012/11/ayat-dan-hadits-tentang-komunikasi.html.

(Accessed on Thursday, 1 December 2017, at 16.14 Wib)

http://amarsuteja.blogspot.co.id/2012/10/.html.

(Accessed on Thursday, 1 December 2017, at $16.30 \mathrm{Wib}$ )

https://makalahkomplit.blogspot.co.id/2012/12/sejarah-berdirinya-fpi.html (Accessed on Friday 16 March 2018, at 20.31 Wib)

http://forum.detik.com/siapa-sih-habib-riziq-ketua-fpi-itu-t41659p87.html

Last edited by noor.icon; 8th December 2008 at 22:25.

https://brainly.co.id/tugas/5138967 (Accessed on Friday 16 March 2018, at 13.57 Wib)

http://opac.fidkom.uinjkt.ac.id/index.php?p=show_detail\&id=7051\&keywords $=\quad($ Accessed on

Monday, 19 March 2018 at 19.20 Wib)

http://eprints.umm.ac.id/986/1/KONSTRUKSI_SURAT_

KABAR_TERHADAP_INSIDEN_MONAS_1_JUNI_2008\%28_Analisis.pdf $=($ Accessed on Monday, 19 March 2018 at $19.30 \mathrm{Wib})$ 
http://www.academia.edu/27192011/Konstruksi_Berita_Tentang_Pembubaran_Ormas_FPI Analisis_Framing_ZhongdanPan_dan_Gerald_M_Kosicki_Pada_Media_Online_Me deka.com_ (Accessed on Monday, 19 March 2018 at $19.25 \mathrm{Wib}$ )

https://www.tribunislam.com/2016/11/kerap-putar-balikan-fakta-dan-sudutkan-islam-kantor berita-metro-TV-didemo.html. (Accessed on Friday, 20 April 2018, at 10.05)

http://ronikurosaky.blogspot.co.id/2014/04/teori-aksi.html

https://sinaukomunikasi.wordpress.com/2011/08/20/analisis-bingkai-framing-analysis/ Accessed on Saturday 10 November 2018 at 10.15 Wib

http://ditpolkom.bappenas.go.id/basedir/Komunikasi/1)\%20Daftar\%20Stasiun\%20TV\%20di\%20 indonesia/TvOne/Sejarah\%20TvOne\%20-\%20daftar\%20stasiun\%20TV\%20

\%20wikipedia.org.pdf (Accessed on 16 November 2018 at $10.32 \mathrm{Wib}$ ) 